\title{
The Internalization of Multiculturalism Values through Literature Learning
}

\author{
Johan Arifin \\ Indonesian Culture and Language Education Department \\ STKIP PGRI Banjarmasin \\ Banjarmasin, Indonesia
}

\author{
Heri Susanto \\ History Education Department \\ Faculty of Teaching and Education \\ Universitas Lambung Mangkurat \\ Banjarmasin, Indonesia
}

\begin{abstract}
Multiculturalism is the identity of a nation which must be understood and internalized in learning practice. Literature learning is an alternative to the internalization of multicultural values. Indonesia is a country that is closely related to nuances of multiculturalism. This situation brings the consequence that multiculturalism must be understood by every citizen not to mention the youth, in this case, learners. Internalization is a process of instilling values or incorporating ideal attitudes previously thought to be external, in order that the values can be incorporated into one's thinking, skills and way of life. The learning of literature as a means of internalizing the nation's culture should be done by involving various parties, especially parents, teachers, and society.
\end{abstract}

Keywords- component, value internalization, multiculturalism, literature.

\section{INTRODUCTION}

Literature is one of the many forms of culture that has become the wealth of the Indonesian nation. The study of school literature, whether in primary school with learners who are still children or in high school with adolescent learners, is usually a part of language learning. It can be understood because the means of literary disclosure is the language. However, it should also be understood that literature, both children literature and adult literature, is more than just language. Language in literary texts is "only" a means aspect although there must be different demands to be a literary language, while the content of the text actually contains morals and values. Literature can be used as a "raw material" of education and character formation of learners through the strategies that fit most. For example, reading literature can be used to learn about life since it teaches the noble values of life, yet learners do not feel being taught. The focus of the discussion is the children's literature with the share of the reader (listener) from children [1].

It is a common understanding that Indonesia is a country with strong nuances of multiculturalism. This situation brings the consequence that multiculturalism must be understood by every citizen including the youth, especially learners. Giving a correct understanding of multiculturalism means eliminating one nation's disintegration opportunities in the future. In the formal educational system, these efforts are substantively the responsibility of disciplines that play an important role in the formation of national identity, including Bahasa Indonesia.

Related to multicultural understanding, good instruction should not stop at the aspects of understanding, but also the internalization of multicultural values. Literary work is an effective medium for the internalization of multicultural values. Through literature learners can understand the cultural context, and the outlook in society that is the background of a literary work.

\section{LITERATURE REVIEW}

Literary work is a result of human creation that contains high beauty value. The beauty of literature comes from a language and a well-orchestrated sense or thought since all forms of literary works are based on clear hearts and thoughts, or in other words, literature is a reflection of one's heart. Thus, to interpret a literary work requires a lot of consideration in determining the purpose and the meaning of a literary work.

One of the literary works is in the form of prose, namely novel as a popular literary work. It is popular not because of the language which is full of rhythm, but because of stories and writing form of the novel which tend to lift the stories or ideas developing in society. Therefore, the contents of a novel are close to the reader.

Literature is a form and result of creative art work whose objects are human and life, using language as its medium [2]. Literary works are not born in a cultural vacuum since literary works are responses to literature that has been previously published. Therefore, a literary text cannot be removed completely from other literary texts [3].

As a work, literature promises something for its readers, namely the value inside it packaged both intrinsically and extrinsically. Therefore, the position of literature becomes important for the development of learners. A work with effective language use will produce an aesthetic experience for learners. The use of imaginative language can produce intellectual and emotional responses in which learners will feel and appreciate the role of the characters and the conflicts they generate, as well as help them appreciate beauty, magic, humor, sadness and injustice. Learners will experience how to 
endure suffering and take risks, will also be challenged to dream, and reflect on as well as bring up various problems about themselves, others and the world around them [4].

The abovementioned literary experience will be obtained by learners from the benefits of a literary work through intrinsic elements in it namely; (1) giving pleasure, joy and enjoyment to the reader, (2) developing learners' imagination and helping them to consider and think about nature, life, experience or ideas in various ways, (3) providing new experiences by themselves (4) developing learners' life insight into humanitarian behavior, (5) presenting and introducing learners to universal experience and (6) passing on the literary heritage. In addition to the intrinsic values, literature also has beneficial extrinsic values for learners' development in the following aspects: (1) language development, (2) cognitive development, (3) personality development, and (4) social development.

The literature created for children is aimed at not only developing imagination, fantasy and cognitive power that will lead children to the emergence of creativity power, but also at leading children to a good understanding of nature and environment and the recognition of feelings and thoughts about themselves and others.

The intrinsic and extrinsic values of the literature is related to the nation's cultural values. The life insights studied through literature are very strong with the cultural values of each region as well as within the national sphere. Universal experiences gained through children's literature will make children understand the insights of the archipelago that indirectly also become the cultural insight of the nation. Furthermore, having a good understanding of these elements will shape the personality and social development of learners based on the nation's culture as a whole.

\section{DISCUSSION}

Internalization is a process of instilling values or incorporating ideal attitudes previously thought as external issues, so the values or attitudes can be incorporated into one's thinking, skills and attitude. Internalization in this sense can also be interpreted as the collection of values or the collection of certain attitudes to form a complete personality (Internalization is essentially a knowledge sharing effort). Internalization can thus be interpreted as one method, procedure and technique in the knowledge management cycle used by educators to provide opportunities for members of a group, organization, agency, company or students to share their knowledge with others [9].

If we learn from literary texts through reading, understanding, and contemplating, we will discover the fact that various concepts of character, nobility fulfilling idealism of how to behave are almost in the form of attitude and behavior. It can be attitude, way of thinking, how to taste, and how to behave verbally and nonverbally. Abstract concepts as discussed in books are embodied in the attitude and behavior of storytellers. The so-called attitudes and behaviors are definitely in accordance with the character that is attached and the form of the attitudes as well as the behaviors depends on the development of the plot. In conclusion, studying life through literary text is like learning directly to the livelihood of society, person per person, case by case, and how all interact in a system that is coherent and harmonious [1].

Studying character, cultural background, and social setting in literary works will indirectly provide cultural understanding for learners. In a lighter and simpler form, reading children's literature will guide children to understand the values contained in each literary work, perceive the aesthetic elements and identify the logic that is embedded in the literary work. Thus, studying the literature of children directly or indirectly is the process of internalizing values in the minds of learners.

In relation to multiculturalism, the character learning is a characteristic of multiculturalism. In accordance with the dynamic character of a society, culture also always experiences reinterpretation and transformation which avoid it from static feature in following the movement of the owner's society [10]. To enable culture to empower the identity of the nation, learners should be guided to do reinterpretation of the multicultural values in the nation and state.

Piaget provides an understanding of the intellectual development of children. One important idea that Piaget puts forward is that the development of intelligence is the result of the interaction of the environment and the maturity of children. Piaget's findings mention that there are different stages in the development of logical thinking. All children experience this same intellectual stage, with the same progress but not necessarily at the same age. Each stage is related to the next stage because a new thinking structure is being developed. Language learning is a learning that plays a very important role in the early development of child's intelligence. This is because the language is a medium to help its users understand the various stimuli, especially in the form of verbal and non verbal information. Accordingly, at this early stage of development, the internalization of cultural values will be easier to do, including through children's literature learning.

The process of internalization is a process of appreciation that lasts throughout the life of the individual from birth until the end of his/her life. Throughout his/her life, one continues to learn to cultivate all the feelings, desires, passions, and emotions that shape the personality. Through the social relationships that exist between individuals and groups, the process of internalization occurs in a person. The internalization process stems from the biological desires and talents of the existing instinct from inheritance in each born individual. However, those which have the most important role in the development of human society are the surrounding, individuals with various characteristics at each level in the process of socialization and enculturation [5]. The first group that introduces cultural values to children is their family and this is where the first interaction and discipline are introduced to them in social life [6]. Ref [7] says that the role of the family for the Javanese is a platform in providing moral guidance, educating family members from childhood to old age by learning the values of Javanese culture. 
This opinion indicates that the learning of literature as a means of internalizing the culture of the nation should be done and involves various parties, mainly parents, teachers, and society. A very traditional method can be applied, for example, by narrative stories that are rich with the nation's character and culture values. In addition, pantun (a type of poem) is easily understood, such as pantun jenaka (funny pantun).

The term "We live surrounded by literature" was borrowed from [8] who wrote the book Metaphors 'We Live by'. In essence, Lakoff and Johnson show the existence and importance of metaphor in human life. In everyday life, man cannot escape from using metaphor, like talking and even thinking by using various metaphors. For example, words that are so commonly heard in everyday conversations such as "falling in love, broken hearts, broken spirits, broken charcoal, stubborn, heart-bearing, exams at the door, hanging sky-high ideals, stumbling" and others are nothing but metaphorical forms. However, people do not realize that these often spoken words are actually metaphors [1]. It indicates that basically in daily life we have been very close to literature. The problem is just how to select the appropriate and acceptable literature for learners and determine positive influence toward the understanding of the nation's culture for learners.

Based on the fact that one can hardly escape from the use of the metaphor, Lakoff \& Johnson assert that "we live surrounded by metaphors, and we cannot live without metaphors". They even state that metaphors 'master' human life, 'master' the way of speaking, thinking, and having culture. It is the same fact that one does not realize the words they speak are metaphors, including their way of thinking and being cultured. It means that we do not realize either the fact that we often think and involve in cultural activities by using metaphors. For example, we see how Banjarese people think and behave. They often convey something with various expressions, speak using symbols, hide something that is preceded, and others of the same kind. These evidences are reflection of living with metaphors.

Thus, the internalization of cultural values through literature will be effective if it is conducted systematically and sustainably in the school environment, family, and society at large. Children's literature learning becomes urgent given that the increasingly eroded culture of the nation in the midst of global trends is always presented in various media

\section{CONCLUSION}

Literature, both children literature and adult literature, are more than simply languages. Literary work is a result of human creation that contains high beauty value. By learning from literary texts through reading, understanding, and contemplating, we will discover the fact that various conceptions of characterized life that meet idealism behavior are almost in the form of attitude and behavior. Language is a medium to help us to understand various stimuli especially in the form of verbal and non-verbal information. Thus, at this early stage of development, the internalization of cultural values will be easier to do, including through children's literature learning. The process of internalization is a process of appreciation that lasts throughout the life of individual. Throughout his/her life, one continues to learn to cultivate all the feelings, desires, passions, and emotions which finally shape their personality. Through the social relationships that exist between individuals and groups, the process of internalization occurs in a person.

\section{REFERENCES}

[1] B. Nurgiyantoro, 'Sastra Anak dan Pembentukan Karakter'. Dalam Jurnal Cakrawala Pendidikan, Mei 2010, Th. XXIX, Edisi Khusus Dies, 2010

[2] M. A Semi, Anatomi Sastra, Padang: Angkasa Raya, 1993

[3] T.N Ganie, Teori Sastra, Banjarmasin: Pusat Pengkajian Masalah Satra, 2011

[4] C.S Huck, S. Hepler, dan J. Hickman, Children's Literature in The, 1987

[5] Koentjaraningrat, Pengantar Antropologi, Jakarta: UI Press, 1980

[6] A. Khairuddin, Proses Komumokasi Dalam Sosiologi. Jakarta: Pustaka Utama, 1997

[7] Geertz, The Interpretation of Cultures, New York: Basic Books Carl Friedrich, 1973

[8] G. Lakoof, dan M. Johnson, Methaphors We Live By, Chicago: The University of Chicago Press, Natalis UNY. 1980

[9] Ihsan, Dasar-Dasar Kependidikan, Jakarta: Rineka cipta, Elementary School, New York: Holt, Rinehart and Winston, 1997

[10] H. Susanto, Seputar Pembelajaran Sejarah, Isu, Gagasan, dan Strategi Pembelajaran,Yogyakarta: Aswaja Presindo, 2014 